\title{
Keterampilan Berpikir Kritis Mahasiswa PGSD Melalui Pembelajaran Read-Answer-Discuss-Explain- And Create (RADEC) yang Berorientasi Penyelidikan
}

\author{
Poppy Anggraeni ${ }^{1,2}$, Wahyu Sopandi ${ }^{1}$, Septinaningrum ${ }^{1,3}$, Ai Hayati ${ }^{1,4}$, \\ Tursinawati $^{1,5}$, Yosi Gumala ${ }^{1,6}$ \\ ${ }^{1}$ Departemen Pendidikan Dasar, Universitas Pendidikan Indonesia, Bandung, Indonesia; \\ wsopandi@upi.edu \\ 2Program Studi PGSD, STKIP Sebelas April Sumedang; poppysofia04@gmail.com \\ 3Program Studi PGMI, IAIN Tulungangung, Indonesia; ningrumseptina@gmail.com \\ ${ }^{4}$ Program Studi PGSD, STKIP Sebelas April Sumedang, Indonesia; ahayati75@gmail.com \\ 5Program Studi PGSD, Universitas Syah Kuala Aceh, Indonesia; tursinawati@unsyiah.ac.id \\ ${ }^{6}$ Program Studi PGSD, Universitas Bhayangkara Jakarta Raya Bekasi, Indonesia; \\ yosi.gumala@dsn.ubharajaya.ac.id
}

Email Koresponding: poppysofia04@upi.edu

\begin{abstract}
Abstrak. Penelitian ini bertujuan untuk memperoleh gambaran secara komprehensif mengenai keterampilan berpikir kritis siswa yang memperoleh pembelajaran RADEC berorientasi penyelidikan. Metode penelitian yang digunakan yaitu mixed methods, dengan sampel sebanyak 29 orang mahasiswa PGSD. Instrumen yang digunakan yaitu tes keterampilan berpikir kritis mengacu pada 5 aspek Critical Thinking Abilities yang dikembangkan Ennis (2011). Hasil penelitian menunjukkan bahwa keterampilan berpikir kritis mahasiswa PGSD pada materi perkembangbiakan pada tumbuhan melalui pembelajaran RADEC berorientasi penyelidikan memiliki kategori cukup $(53,4 \%)$. Adapun keterampilan berpikir kritis tertinggi pada aspek the bases for a decision (59,1\%) dan persentase terendah pada aspek basic clarification $(44,5 \%)$. Hasil uji hipotesis menggunakan software SPSS 22 menunjukkan bahwa tidak terdapat perbedaan yang signifikan keterampilan berpikir kritis antara mahasiswa PGSD perempuan dan laki-laki. Namun demikian, nilai rata-rata keterampilan berpikir kritis perempuan $(55,3)$ lebih besar daripada laki-laki $(45,8)$, maka dapat disimpulkan keterampilan berpikir kritis mahasiswa PGSD perempuan lebih tinggi daripada keterampilan berpikir kritis mahasiswa PGSD laki-laki.
\end{abstract}

Kata kunci: Keterampilan berpikir kritis, RADEC, Penyelidikan

\begin{abstract}
This study aims to obtain a comprehensive picture of the critical thinking skills of students who receive inquiry-oriented $R A D E C$ learning. The research method used is mixed methods, with a sample of 29 PGSD students. The instrument used is the critical thinking skills test which refers to the 5 aspects of Critical Thinking Abilities developed by Ennis (2011). The results showed that the critical thinking skills of PGSD students on the material of plant breeding through inquiry-oriented RADEC learning were in a sufficient category (53.4\%). The highest critical thinking skills were in the bases for a decision aspect (59.1\%) and the lowest percentage was in the basic clarification aspect (44.5\%). The results of hypothesis testing using SPSS 22 software show that there is no significant difference in critical thinking skills between female and male PGSD students. However, the average value of women's critical thinking skills (55.3) is greater than that of men (45.8), it can be concluded that female PGSD students 'critical thinking skills are higher than male PGSD students' critical thinking skills.

Keywords: Critical thinking skills, RADEC, Inquiry
\end{abstract}




\section{Pendahuluan}

Pembelajaran merupakan suatu proses interaksi dan komunikasi antara siswa, guru dan lingkungan belajar. Guru memegang peranan yang sangat penting dalam suatu proses pembelajaran karena guru harus merencanakan sebuah pembelajaran yang dapat memfasilitasi siswa untuk belajar, sehingga siswa dapat mengembangkan berbagai pengetahuan, keterampilan dan sikapnya sebagai hasil dari pembelajaran.

Salah satu keterampilan yang penting untuk dimiliki oleh siswa saat ini adalah keterampilan berpikir kritis, keterampilan ini harus dikembangkan oleh setiap individu di abad 21 karena tuntutan zaman semakin tinggi sehingga diperlukan individu yang memiliki multi keterampilan yang mampu memecahkan setiap permasalahan saat ini.

Ungkapan berpikir kritis diawali oleh Dewey (1910) yang lebih sering disebut berpikir reflektif. Ia mengartikannya sebagai aktif, gigih, dan pertimbangan yang hati-hati terhadap sesuatu yang diyakini atau yang seharusnya dari suatu pengetahuan dasar yang mendukungnya dan lebih jauh lagi terhadap kecenderungan suatu kesimpulan (Standford Encyclopeda Of Philosophy, 2018). Menurut Scriven \& Paul (1987) berpikir kritis adalah adalah proses intelektual disiplin aktif dan terampil dalam mengkonseptualisasi, menerapkan, menganalisa, mensintesis, dan/atau mengevaluasi informasi yang dikumpulkan dari, atau dihasilkan oleh pengamatan, pengalaman, refleksi, penalaran, atau komunikasi, sebagai panduan dalam meyakini dan melakukan aksi The Foundation of Critical Thinking (2019).

The new Australian Curriculum (AC) telah memiliki tujuan mempersiapkan peserta didik untuk abad kedua puluh satu, dan menekankan pengembangan kritis (dan pemikiran kreatif) sebagai salah satu "kemampuan umum" peserta didik. Berpikir kritis dipandang sebagai kunci dalam mempersiapkan "siswa untuk hidup dan bekerja di abad ke-21" dan "dasar untuk pembelajaran yang efektif" (Ab Kadir, 2018). Selain itu dalam Foundation for Young Australians (2016) FYA's New Work Order report series dengan judul "THE NEW BASICS: Big data reveals the skills young people need for the New Work Order" mengungkapkan bahwa proporsi pertumbuhan kebutuhan keterampilan pada awal karir tahun 2012-2015 pada aspek berpikir kritis menempati posisi kedua setelah literasi digital dengan persentase sebesar $158 \%$.

Di Indonesia pentingnya pengembangan berpikir kritis telah disebutkan dalam PP Nomor 20 Tahun 2016 bahwa pada dimensi keterampilam siswa SD/MI/SLB/Paket A harus memiliki keterampilan berpikir dan bertindak yang 
meliputi kreatif, produktif, kritis, mandiri, kolaboratif, dan komunikatif melalui pendekatan ilmiah sesuai dengan tahap perkembangan anak. Selain itu dalam PP Nomor 81A Tahun 2013 bahwa proses pembelajaran terdiri atas lima pengalaman belajar pokok yaitu mengamati; menanya; mengumpulkan informasi; mengasosiasi; dan mengkomunikasikan. Pada bagian menanya, kompetensi yang dikembangkan adalah mengembangkan kreativitas, rasa ingin tahu, kemampuan merumuskan pertanyaan untuk membentuk pikiran kritis yang perlu untuk hidup cerdas dan belajar sepanjang hayat.

Salah satu pembelajaran yang selama ini dibuktikan dapat meningkatkan kemampuan berpikir kritis siswa adalah pembelajaran inkuiri. Penelitian sebelumnya menunjukkan pembelajaran dengan inkuiri terbimbing meningkatkan keterampilan berpikir kritis siswa kelas V SDN Cimalaka Sumedang (Nurhayati et al., 2017); terdapat perbedaan kemampuan berpikir kritis antara siswa kelas VIII SMP 1 Meulaboh Aceh yang menggunakan strategi pembelajaran inkuri berbasis multiliterasi dengan kelas yang menggunakan pembelajaran konvensional (Julianda et al., 2018); terdapat pengaruh yang signifikan dari metode pengajaran inkuiri terbimbing pada total skor pemikiran kritis siswa SMP di Iran (Azizmalayeri et al, 2012); keterampilan berpikir kritis siswa kelas X SMA di Malang yang diajarkan dengan menggunakan inkuiri - model penemuan melalui studi empiris dan teoritis lebih tinggi daripada siswa yang diajarkan dengan menggunakan pembelajaran konvensional (Wartono et al., 2018); keterampilan berpikir kritis siswa pada sekolah tinggi di Thailand dapat ditingkatkan melalui pengajaran dan pembelajaran berbasis inkuiri (Thaiposri \& Wannapiroon, 2015); model pembelajaran inkuiri bebas yang dimodifikasi efektif digunakan untuk melatih keterampilan berpikir kritis mahasiswa matematika IKIP Mataram (Hadi et al., 2018); pendekatan penyelidikan berbasis argumen secara signifikan dapat meningkatkan pemikiran kritis dan kesuksesan pemahaman konseptual optik di antara calon guru sains di Turki (Memis, 2016) serta masih banyak lagi penelitian lainnya.

Penelitian tersebut telah banyak dilaksanakan baik di tingkat SD, SMP, maupun SMA ataupun pada mahasiswa calon guru, dengan kata lain area jenjang penelitiannya telah lengkap, sehingga diperlukan alternatif pembelajaran lain yang dapat meningkatkan keterampilan berpikir kritis siswa. Selain itu terdapat beberapa penyebab mengapa guru kesulitan dalam mengaplikasikan pembelajaran inkuiri pada proses pembelajaran diantaranya harus adanya kesiapan mental pada siswa, perlu adanya penyesuaian/ adaptasi dari metode tradisional, sulit untuk mengontrol kegiatan dan keberhasilan siswa karena penilaian fokus pada penguasaan materi pelajaran, 
membutuhkan waktu yang panjang atau guru mengalami kesulitan dalam menyesuaikan waktu (Setiawati \& Kusmaryono, 2013).

Penyebab sulitnya implementasi pembelajaran inkuri ini terjadi karena pembelajaran inkuiri ini diadaptasi dari luar negeri, dimana pengembang pembelajaran hanya memperhatikan kondisi dan situasi dimana pembebelajaran inkuiri ini pertama kali dilaksanakan. Adapun situasi dan kondisi di Indonesia boleh jadi memiliki ketidaksesuaian dalam aplikasi pembelajaran inkuiri ini. Sehingga hal ini menjadi tantangan bagi guru atau peneliti untuk dapat mengembangkan pembelajaran yang sesuai dengan kondisi di sekolah yang dapat melatihkan siswa melakukan penyelidikan sehingga melalui pembelajaran tersebut tetap mampu meningkatkan keterampilan berpikir kritis siswa.

Salah satu model inovatif yang merupakan hasil pengembangan pembelajaran yang sesuai dengan kondisi dan situasi di Indonesia adalah pembelajaran RADEC. Pembelajaran RADEC ini dapat digunakan oleh guru sebagai sarana dalam mengembangkan keterampilan abad 21 siswa (Sopandi \& Handayani, 2018). Berdasarkan aspek kesiapan, gain dari kesiapan aspek kognitif dan emosional-sikap berada dalam kategori sangat siap, dan aspek perilaku berada dalam kategori siap. Penelitian (Satria \& Sopandi, 2019) menunjukkan bahwa guru sains dasar tidak berorientasi pada peningkatan berpikir kritis di antara siswa, karena sangat sedikit siswa yang menunjukkan keterampilan berpikir kritis, dengan demikian model RADEC yang dikembangkan dari penelitiannya ini dapat digunakan sebagai alat untuk menilai kelas IPA mengenai peningkatan berpikir kritis siswa sekolah dasar.

Berdasarkan kesiapan implementasi pembelajaran RADEC dan adanya bukti bahwa pembelajaran inkuiri dapat meningkatkan keterampilan berpikir kritis siswa maka kebaruan pada penelitian ini adalah pada penerapan pembelajaran RADEC yang dikaitkan dengan pembelajaran inkuiri sehingga menjadi pembelajaran RADEC yang berorientasi penyelidikan. Melalui penerapan pembelajaran RADEC berorientasi penyelidikan ini diharapkan dapat menjadi salah satu alternatif pembelajaran yang dapat meningkatkan kemapuan berpikir kritis siswa. Adapun tujuan penelitian ini adalah untuk memperoleh gambaran secara komprehensif tentang keterampilan berpikir kritis siswa yang memperoleh pembelajaran RADEC berorientasi penyelidikan.

\section{Metode}

Metode penelitian yang digunakan yaitu mixed methods yaitu metodologi penelitian mencampurkan data kuantitatif dan data kualitatif dalam suatu 
penyelidikan. Jadi dalam penelitian ini dilakukan analisis data secara deskriptif dan menggunakan desain penelitian eksperimen type one shot case study.

Sampel pada penelitian ini adalah mahasiswa Program Study PGSD STKIP Sebelas April Sumedang semester 2 yang berjumlah 29 orang. Waktu penelitian ini dilakukan pada hari Selasa tanggal 18 Juni 2019 di Kampus II STKIP Sebelas April Sumedang. Peneliti menggunakan instrumen pengumpulan data berupa tes individu keterampilan berpikir kritis. Instrument keterampilan berpikir kritis mengacu pada Critical Thinking Abilities yang dikembangkan Ennis (2011).

Uji validitas dilakukan dengan melihat validitas isi dan validitas konstruk dari instrument yang digunakan. Uji validitas dan reliabilitas dilakukan melalui uji coba instrument terlebih dahulu. Selanjutnya skor hasil uji coba dianalisis menggunakan software SPSS 22 untuk mengetahui kriteria validitas dan reliabilitas dari instrument yang akan digunakan dalam penelitian.

Analisis data keterampilan berpikir kritis dilakukan dengan menghitung skor jawaban benar siswa. Skala yang digunakan yaitu skala 100, dengan menggunakan rumus berikut ini.

$$
\text { Nilai akhir }=\frac{\text { jumlah skor yang diperoleh }}{\text { jumlah skor ideal }} \times 100
$$

Sedangkan untuk memperoleh persentase kemampuan berpikir kritis maka dapat digunakan rumus berikut ini.

$$
\text { Keterampilan berpikir kritis }=\frac{j u m l a h \text { skor yang diperoleh }}{\text { jumlah skor ideal }} \times 100 \%
$$

Sebagai standar pengelompokan keterampilan berpikir kritis yang diteliti, maka digunakan kriteria (Akdon, 2008: 119-120) sebagai berikut.

Tabel 1. Kriteria Keterampilan Berpikir Kritis

\begin{tabular}{cc}
\hline Persentase $(\%)$ & Kriteria \\
\hline $81-100$ & Sangat Tinggi \\
$61-80$ & Tinggi \\
$41-60$ & Cukup \\
$21-40$ & Rendah \\
$0-20$ & Sangat Rendah \\
\hline
\end{tabular}


Untuk menjawab hipotesis penelitian apakah terdapat perbedaan kemampuan berpikir kritis mahasiswa PGSD perempuan dengan laki-laki, maka dilakukan uji hipotesis menggunakan SPSS 22 dengan menggunakan uji hipotesis double mean yaitu uji t dengan berdasarkan pada skor keterampilan berpikir kritis mahasiswa perempuan dan siswa laki-laki.

\section{Hasil dan Pembahasan}

Keterampilan berpikir kritis (basic clarification, the bases for a decision, inference, advanced clarification; dan supposition and integration) mahasiswa PGSD pada materi perkembangbiakan tumbuhan melalui pembelajaran RADEC berorientasi penyelidikan memiliki rata-rata sekitar $53,4 \%$ atau berada pada kategori cukup. Menurut (C21 Canada, 2012) berpikir kritis adalah kemampuan untuk memperoleh, memproses, menafsirkan, merasionalisasi dan analisis kritis terhadap informasi yang saling bertentangan hingga membuat keputusan dan mengambil informasi tindakan secara tepat waktu. Menurut (Facione, 1990) semua pembelajaran harus dapat mengembangkan pemikir kritis yang baik. Karena menurut (Alban, 2020) sesorang yang memiliki keterampilan berpikir kritis, maka akan sangat membantu ketika akan menganalisis suatu informasi, memecahkan masalah secara sistematis, menghasilkan solusi yang inovatif, merencanakan secara strategis, berpikir secara kreatif, dan mampu mempresentasikan karya atau idenya kepada orang lain dengan cara yang mudah dipahami.

Adapun persentase pada setiap aspek keterampilan berpikir kritis dapat dilihat pada gambar 1 berikut ini.

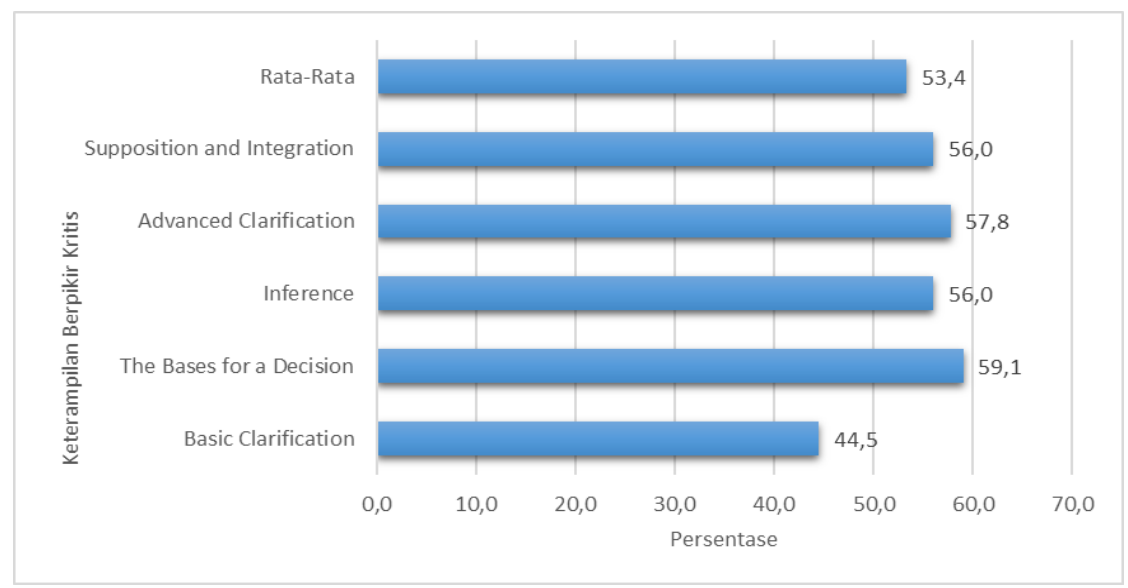

Gambar 1. Profil Keterampilan Berpikir Kritis

Berdasarkan gambar di atas dapat diketahui bahwa terdapat variasi terhadap keterampilan berpikir kritis mahasiswa PGSD, dengan persentase tertinggi pada aspek the bases for a decision dan persentase terendah pada aspek basic 
clarification, namun demikian keduanya sama-sama berada pada kategori cukup. Penelitian (Karlina et al., 2020) menunjukkan bahwa terdapat peningkatan berpikir kritis siswa melalui penerapan model pembelajaran RADEC.

Keterampilan berpikir kritis mahasiswa PGSD pada aspek pertama Basic Clarification memiliki kategori cukup, artinya mahasiswa sudah memiliki keterampilan dalam klarifikasi dasar. Pada indikator fokus pada pertanyaan yaitu memiliki keterampilan yang rendah dalam mengidentifikasi atau merumuskan pertanyaan (37,9\%), keterampilan yang cukup dalam mengidentifikasi atau merumuskan kriteria untuk menentukan jawaban yang mungkin.(44,8\%), dan memiliki keterampilan yang cukup dalam bertanya dan mengklarifikasi jawaban atau pertanyaan tantangan pada menentukan point utama $(50,9 \%)$.

Keterampilan berpikir kritis mahasiswa PGSD pada aspek kedua The Bases for a Decision memiliki kategori cukup, artinya mahasiswa sudah memiliki keterampilan yang cukup dalam memberikan alasan untuk suatu keputusan. Pada indikator mempertimbangkan kredibilitas suatu sumber, mahasiswa memiliki keterampilan yang tinggi dalam kemampuan memberikan alasan $(66,4 \%)$, sedangkan pada indikator mengobservasi dan mempertimbangkan hasil observasi memiliki keterampilan yang cukup dalam kemungkinan menguatkan (51,7\%).

Keterampilan berpikir kritis mahasiswa PGSD pada aspek ketiga Inference memiliki kategori cukup, artinya mahasiswa sudah memiliki keterampilan yang cukup dalam menyimpulkan. Pada indikator membuat kesimpulan material, mahasiswa memiliki keterampilan yang tinggi dalam mengusulkan kesimpulan yang konsisten dengan semua fakta yang diketahui (77,6\%), memiliki keterampilan yang cukup dalam menggeneralisasikan $(46,6 \%)$ dan engusulkan kesimpulan yang mungkin dan sederhana yang sesuai dengan gambar $(44,0 \%)$.

Keterampilan berpikir kritis mahasiswa PGSD pada aspek keempat Advanced Clarification memiliki kategori cukup, artinya mahasiswa sudah memiliki keterampilan yang cukup dalam mengkarifikasi lebih lanjut. Pada indikator menentukan istilah dan mempertimbangkan definisi menggunakan kriteria yang sesuai, mahasiswa memiliki keterampilan yang cukup dalam mengkasifikasikan (57,8\%). 
Keterampilan berpikir kritis mahasiswa PGSD pada aspek kelima Supposition and Integration memiliki kategori cukup, artinya mahasiswa sudah memiliki keterampilan yang cukup dalam melakukan dugaan dan keterpaduan. Pada indikator mempertimbangkan alasan dari premis, alasan, asumsi, posisi, dan usulan lain yang tidak disetujui oleh mereka atau yang membuat mereka merasa ragu tanpa membuat ketidaksepakatan atau keraguan itu mengganggu pikiran mereka memiliki keterampilan yang cukup (56,0\%).

Adapun keterampilan berpikir kritis mahasiswa PGSD berdasarkan jenis kelamin dapat dilihat pada tabel di bawah ini.

Tabel 2. Profil Keterampilan Berpikir Kritis Berdasarkan Jenis Kelamin

\begin{tabular}{llll}
\hline \multirow{2}{*}{ No } & \multirow{2}{*}{ Keterampilan Berpikir Kritis } & \multicolumn{2}{c}{ Jenis Kelamin } \\
\cline { 3 - 4 } & & Perempuan & Laki-laki \\
\hline 1 & Basic Clarification & 45,3 & 41,7 \\
2 & The Bases for a Decision & 60,9 & 52,1 \\
3 & Inference & 58.0 & 48,6 \\
4 & Advanced Clarification & 64.1 & 33,3 \\
5 & Supposition and Integration & 57,6 & 50 \\
\hline & Rata-Rata & 55,3 & 45,8 \\
\hline & Persentase & 55,3 & 45,8 \\
\hline & Kategori & Cukup & Cukup
\end{tabular}

Berdasarkan tabel di atas dapat diketahui bahwa persentase keterampilan berpikir kritis mahasiswa PGSD perempuan lebih tinggi daripada laki-laki, namun demikian keduanya berada pada kategori cukup.

Untuk mengetahui apakah terdapat perbedaan keterampilan berpikir kritis antara mahasiswa PGSD perempuan dan laki-laki maka dilakukan uji hipotesis dengan uji double mean menggunakan software SPSS 22. Berdasarkan tabel independent samples test diperoleh nilai sig. (2-tailed) 0,456 dan nilai ini lebih besar dari nilai $\alpha=0,05$, maka $\mathrm{H}_{0}$ diterima. Karena $\mathrm{H}_{1}$ ditolak maka tidak terdapat perbedaan yang signifikan keterampilan berpikir kritis mahasiswa yang berjenis kelamin perempuan dan berjenis kelamin laki-laki. Karena ratarata nilai keterampilan berpikir kritis perempuan $(55,3)$ lebih besar daripada laki-laki $(45,8)$, maka dapat dikatakan keterampilan berpikir kritis perempuan lebih tinggi daripada keterampilan berpikir kritis laki-laki. Hal ini sesuai dengan hasil penelitian (Mashami \& Gunawan, 2018) yang menyimpulkan bahwa keterampilan berpikir kritis siswa perempuan lebih tinggi daripada siswa laki-laki. 
Menurut (Pratama et al., 2019) keterampilan berpikir kritis sangat penting untuk dikembangkan karena adanya tuntutan perubahan waktu. Seperti diketahui perubahan waktu dan tuntutan jaman seperti di abad ke 21 ini memerlukan manusia yang memikili kompetensi abad 21 agar mampu beradaptasi dengan baik, mampu menghadapi berbagai tantangan dan dapat memecahkan bErbagai permasalahan yang dihadapi.

\section{Simpulan}

Berdasarkan pada penelitian yang telah dilakukan dapat disimpulkan bahwa keterampilan berpikir kritis mahasiswa PGSD pada materi perkembangbiakan pada tumbuhan melalui pembelajaran RADEC berorientasi penyelidikan memiliki kategori cukup (53,4\%). Berdasarkan indikatornya diketahui keterampilan berpikir kritisnya memiliki persentase yang bervariasi, namun semuanya memiliki kategori cukup, dengan keterampilan berpikir kritis tertinggi pada aspek the bases for a decision $(59,1 \%)$ dan persentase terendah pada aspek basic clarification (44,5\%).

Hasil uji hipotesis menggunakan software SPSS 22 menunjukkan bahwa tidak terdapat perbedaan yang signifikan keterampilan berpikir kritis antara mahasiswa PGSD perempuan dan laki-laki. Meskipun demikian, rata-rata nilai keterampilan berpikir kritis perempuan $(55,3)$ lebih besar daripada lakilaki $(45,8)$, sehingga dapat dikatakan keterampilan berpikir kritis perempuan lebih tinggi daripada keterampilan berpikir kritis laki-laki.

Penelitian lebih lanjut mengenai penerapan pembelajaran RADEC berorientasi penyelidikan dapat dilakukan pada materi IPA yang berbeda sehingga diperoleh hasil yang lebih banyak dan relevan dalam mendukung pengembangan keterampilan berpikir kritis baik siswa SD, SMP, SMA maupun mahasiswa.

\section{Daftar Pustaka}

Ab Kadir, M. A. (2018). An inquiry into critical thinking in the Australian curriculum: examining its conceptual understandings and their implications on developing critical thinking as a "general capability" on teachers' practice and knowledge. Asia Pacific Journal of Education, 38(4), 533-549.

Alban, D. (2020). Why Critical Thinking Is Important (E how to improve it) I Be Brain Fit. Be Brain Fit \& Blue Sage. https://bebrainfit.com/critical-thinking/

Azizmalayeri, et al. (2012). The impact of guided inquiry methods of teaching on the critical thinking of high school students. Journal of Education and Practice, 3(10), 42-48.

C21. (2012). Shifting mindsets: A 21ST CENTURY VISION OF PUBLIC EDUCATION FOR CANADA. C21 Canada. www.c21canada.org

Facione, P. A. (1990). Critical Thinking: A Statement of Expert Consensus for Purposes of Educational Assessment and Instruction. In The Complete American Philosophical 
Association Delphi Research Report is available as ERIC Doc. No.: ED 315423. https://doi.org/10.1017/CBO9780511804632

Hadi, S. A., Susantini, E., \& Agustini, R. (2018). Training of Students ' Critical Thinking Skills through the implementation of a Modified Free Inquiry Model Training of Students ' Critical Thinking Skills through the implementation of a Modified Free Inquiry Model. Journal of Physics: Conference Series PAPER.

Julianda, Widiati, U., \& Djatmika, E. T. (2018). Pengaruh Strategi Pembelajaran Inkuiri Berbasis Keterampilan Multiliterasi terhadap Kemampuan Berpikir Kritis Siswa. Jurnal Pendidikan: Teori, Penelitian, Dan Pengembangan, 2012, 460-467.

Karlina, D., Sopandi, W., \& Sujana, A. (2020). Critical Thinking Skills of Fourth Grade in Light Properties Materials through the Radec Model. The 2nd International Conference on Elementary Education, 2, 1743-1753. http://proceedings.upi.edu/index.php/icee/article/view/802/720

Mashami, R. A., \& Gunawan, G. (2018). The Influence of Sub-Microscopic Media Animation on Students' Critical Thinking Skills Based on Gender. Journal of Physics: Conference Series, 1108(1), 1-8.

Memis, E. K. (2016). The Effects of an Argument-Based Inquiry Approach On Improving Critical Thinking and the Conceptual Understanding of Optics among Pre-Service Science Teachers. International Journal of Progresive Education, 12(3), 61-77.

Nurhayati, A. R., Jayadinata, A. K., \& Sujana, A. (2017). Keterampilan Berpikir Kritis Siswa Kelas V Pada Materi Daur. Jurnal Pena Ilmiah, 2(1), 1061-1070.

Pratama, Y. A., Sopandi, W., \& Hidayah, Y. (2019). RADEC Learning Model (Read-AnswerDiscuss-Explain And Create): The Importance of Building Critical Thinking Skills In Indonesian Context. International Journal for Educational and Vocational Studies, 1(2), 109115.

Satria, E., \& Sopandi, W. (2019). Applying RADEC model in science learning to promoting students' critical thinking in elementary school. Journal of Physics: Conference Series, 1321(3).

Setiawati, R., \& Kusmaryono, H. (2013). Penerapan Inquiry Based Learning Untuk Mengetahui Respon Belajar Siswa Pada Materi Konsep Dan Pengelolaan Koperasi. Jurnal Pendidikan Ekonomi Dinamika Pendidikan, VIII(2), 133-145.

Sopandi, W., \& Handayani, H. (2018). The Impact of Workshop on Implementation of ( RADEC ) Learning Model on Pedagogic Competency of Elementary School Teachers. Advances in Social Science, Education and Humanities Research, Volume 178 1st International Conference of Innovation in Education (ICoIE 2018) The, 178(1st International Conference of Innovation in Education (ICoIE 2018)), 7-11.

Thaiposri, P., \& Wannapiroon, P. (2015). Enhancing students ' critical thinking skills through teaching and learning by inquiry-based learning activities using social network and cloud computing. Procedia - Social and Behavioral Sciences, 174, 2137-2144.

Wartono, W., Hudha, M. N., \& Batlolona, J. R. (2018). How Are The Physics Critical Thinking Skills of The Students Taught by Using Inquiry-Discovery Through Empirical and Theorethical Overview? EURASIA Journal of Mathematics, Science and Technology Education, 14(2), 691-697. 